DOI: 10.21625/resourceedings.v2i2.612

\title{
The effect of the reciprocal relations of the deterioration symptoms in different building materials in some of historic Cairo's buildings
}

\author{
Essam H. Mohamed ${ }^{1}$ \\ ${ }^{1}$ Archaeology conservation Department, Faculty of archaeology, South valley university, Qena, Egypt,
}

Email: Essam.mohamed@arch.svu.edu.eg

\begin{abstract}
In the present study, since historic Cairo established, limestone and woods have been used for building construction alongside. The building materials representing case studies in historic Cairo are affected by different deterioration factors, such as rising ground water level, the salt weathering, air pollution, frequency between temperature and relative humidity, and microbiological deterioration.

From case studies survey various types of weathering forms were observed, such as granular disintegration, splitting in the wooden lintel, the efflorescence of salt, pitting in limestone surface, black spots in limestone surface due to microbiological deterioration, black crust and peeling, flaking of painting layers, etc. The aim of this study is to identify on the reciprocal relations of the deterioration symptoms in different building materials (limestone - wood) used in some of historic Cairo's buildings. The samples were collected from different sites, investigated by several scientific techniques such as X-Ray Diffraction (XRD), EDX analytical methods, Fourier Transform Infrared Microscopy (FTIR) to detect the changes of the main wood components (cellulose, hemicellulose, lignin), Scanning Electron Microscopy (SEM), Polarizing Light Microscopy (PLM), Stereo Microscopy, and microbiological investigation were also done. The results of the study indicated that there was a fungal infection on the surface of limestone, in particular which is found close to the wooden elements, microbiological investigation was shown the following fungi: Aspergillus flavus, Aspergillus terreus, Aspergillus niger, Aspergillus fumigatus, Clado Sporium, Saccharomyces. From investigation of wood samples are shown that there is a rise moisture content in the wood materials, due to direct connection between them and adjacent the stones, in addition to crystallized salts found in wood fiber and internal structure of limestone, such as $\mathrm{NaCl}, \mathrm{CaSO} 4.2 \mathrm{H} 2 \mathrm{O}, \mathrm{CaSO} 4$; due to the effect of building material properties on each other. Furthermore, the physical and mechanical properties tests of building materials indicated that reduction in its properties.
\end{abstract}

(C) 2019 The Authors. Published by IEREK press. This is an open access article under the CC BY license (https://creativecommons.org/licenses/by/4.0/).

Keywords

Building materials; deterioration symptoms; limestone; wooden elements; historic Cairo

\section{Introduction}

The building materials used in Archaeological Islamic buildings in historic Cairo have been suffering from several deterioration factors such as rising ground water level, air pollution, and variation between temperature and relative humidity, in addition to microbiological deterioration. The limestone considered one of the most important stones 
in which used in building construction in historic Cairo (Collepardi,1990), The physico- chemical changes that occur in the mineral composition of limestone are a direct result of the physico-chemical disparity between the stone's internal structure and the surrounding environment (Abd Elhady, 199 7\& Ismail, 2003). The wetting and drying cycles can cause erosion of the external surface of the stone, in particular when salts are found in the pores of stone, the limestone is more sensitive to thermal expansion where calcite expands along one crystallographic Axia and contracts in the other two (Grossi \& Brimblecombe, 2007). Moisture is essential for microbial to grow on wood surface used in historic buildings, in addition to moisture, many other factors influence micro organism growth, such as temperature, pH, nitrogen, and other nutrients (Eriksson et.al., 2012). The rate of the building materials damage is more serious in urban areas due to increase effects of sulfuric dioxids (Fassina, 1991).

Air pollution cause to the physico-chemical deterioration of building materials due to direct contact between sulfuric acid and building material's surface, in which is found in building materials. Pollution products cover the surface of building materials with b lack hard crust. The surface of stone down this crust is becoming crisp and losts of coherence, due to the physico-chemical interactions between the stone components and gases of air pollution Abd (Elhady,1995). Discoloration and degradation of stone in historic buildings could be caused by the fungal ability in the production of pigments and organic acids (Gupta \& Sharma, 2012). The aim of this study was to obtain interpretation of the reciprocal relations of the deterioration symptoms in different building materials (limestone - wood), used in some of historic Cairo's buildings, to find the appropriate plan of conservation.

\section{The case studies}

Building materials for five sites: Madrasa of Sultan Hassan (757 - 764)AH /(1356 - 1363) AD, Al maridani mosque(739- 740 AH /1338 - 1339 AD), Madrasa of Qanibay alrammah (908 AH /1502AD), Madrasa of Gawhar al-Lala (833 AH /1430AD), and Al Mahmoudi a Mosque (1035 AH - 1625 AD)) were studied, that sites considered as a part of Historic Cairo were registered in the World Cultural Heritage List in 1979.

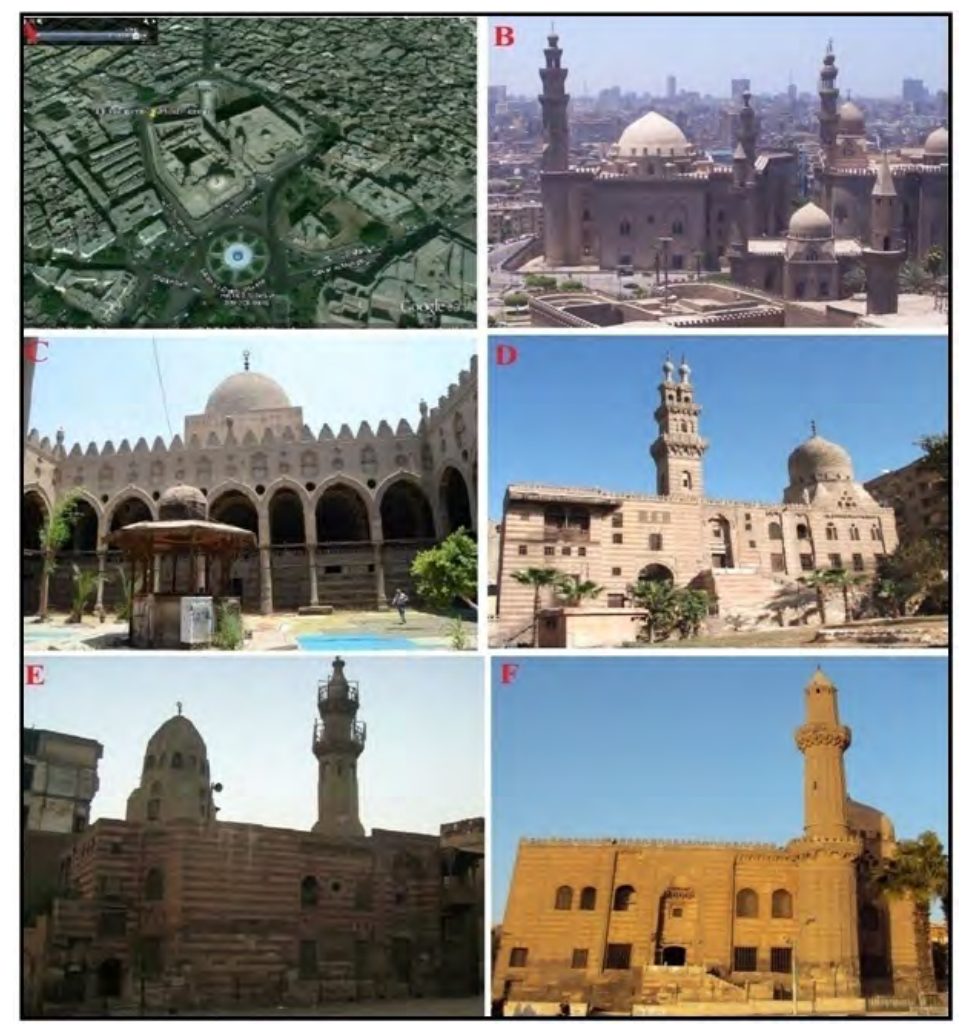

Figure 1. A- Case studies sites(Google earth) B- Madrasaof Sultan Hassan C- Al maridani mosque D- Madrasa of Qanibay alrammah E- Madrasa of Gawhar al-Lala F- Al MahmoudiaMosque 


\subsection{Deterioration causes of building materials}

The case studies have been suffering from the effect of moisture, The essential source of moisture is rising ground water level, resulting in the presence, deterioration in building materials (limestone - wood) (Hamid, 2006), the effect of ground water is increased in the presence of other deterioration factors, such as air pollution, Frequency between temperature and relative humidity, and salts (Abd Elhady, 1995). The ground water containing various kinds of mineral salts, in which they are the most important physiochemical weathering and damage processes that affect building materials (Hemeda, 2018), when ground water level rises to building material's pores by capillary properties, the mineral salts were penetrating the pores of $s$ tones, micro cracks in the mineral crystals occurred due to crystallization and re -crystallization pressure (Scheme, 2000). The salts inside the pores can be increased moisture content of the stone, due to attract of molecules of water (Prikryl, 2007), in particular sodium chloride salt, in which it is characterized with Hygroscopic property (Charola, 2000, \& Honey borne,1990). Sodium chloride salt has reacted with limestone (calcium carbonate), calcium carbonate partially change into calcium chloride (soluble in water) according to the following equations:

$$
\begin{aligned}
& \mathrm{CaCO}_{3}+2 \mathrm{NaCl} \rightarrow \mathrm{CaCl}_{2}+\mathrm{Na}_{2} \mathrm{CO}_{3} \\
& \mathrm{CaCO}_{3}+\mathrm{CO}_{2}+\mathrm{H}_{2} \mathrm{O} \rightarrow \underset{\mathrm{Ca}+2 \mathrm{HCO}_{3}}{\mathrm{Calcium} \text { carbonate }} \quad\left(\mathrm{Ca}\left(\mathrm{HCO}_{3}\right)_{2}\right)
\end{aligned}
$$

$$
\mathrm{CaCO}_{3}+\mathrm{SO}_{3}+\mathrm{H}_{2} \mathrm{O} \rightarrow \mathrm{CaSO}_{4} \cdot 2 \mathrm{H}_{2} \mathrm{O}+\mathrm{CO}_{2}
$$

Due to the high moisture content of the stones in buildings, the wood is affected and absorbs the soluble salts from adjacent stones, because the wood is a hygroscopic material that absorbs moisture from the surrounding atmosphere easily. As a result of its high porosity, it absorbs water between $20 \%$ and $30 \%$ and in the presence of moisture a hydrolysis of cellulose and hemi cellulose occurs. Cellulose retains the basic structure of the fibers in the initial stages, and continuing decomposition physio chemical properties is drop ping, due to dissolve and damage the secondary wall of the wood cells. From the examination of the wood samples, we observed that there is loss of wood durability.

Wood exposed to severe changes to its chemical and physical properties due to the combined effect of moisture, oxygen, atmospheric pollutants and micro-organisms. Oxygen and sol ar radiation can rapidly induce oxidation of lignin and hemicellulose and de polymerisation of cellulose, many of the reaction products are water-soluble so they are easily removed from the wood surface by rain, which leading to a material loss and a roughened and discolored surface, (George, et.al. 2005 \& Xie, et.al. 2005).

Different weathering forms were observed, such as Loss of stone material, missing parts, erosion of stone surfaces, exfoliation, efflorescence of salt, Pitting, chipping of $\mathrm{f}$ pieces, Black hard crust, peeling, granular disintegration, roughening, and soiling, addition to accumulation of dust and salt particles on stone surface, and b lack spots on limestone surface causes microbiological damage. Deterioration features of wooden elements was separation of texture, crack, crumbling, flaking of paint layer s, splitting and deflection of wooden lintel.

\subsection{Symptoms of deterioration (Figure 2)}

- Loss of stone material and separation of wooden texture addition to accumulation of dust and salt particles inside wooden texture (Al maridani mosque, Figure 2A).

- Splitting in wooden lintel (Madrasa of Qanibay alrammah, Figure 2H) .

- Loss of stone material, and separation of wooden texture addition to accumulation of dust and salt particles inside wooden texture (Al maridani mosque, Figure $2 \mathrm{~J}$ ). 
- Deflection of wooden lintel (Madrasa of Qanibay alrammah, Figure 2C).

- Flaking and crumbling of paint layer (Al Mahmoudia Mosque, Figure 2E).

- C rack and flaking of paint layer of wooden door (Madrasa of Sultan Hassan, Figure 2D)

- Splitting in wooden door and the paint flakes with thick layers dropping off in big particles (Madrasa of Gawhar al-Lala, Figure 2I).

- Pitting on the limestone surface (Al Mahmoudia Mosque, Figure 2M).

- Black spots on limestone surface cause biological damage (Al Mahmoudia Mosque, Figure 2B).

- Loss of stone material (Madrasa of Sultan Hassan, Figure 2L).

- Black crust and peeling (Madrasa of Gawhar al-Lala, Figure 2K).

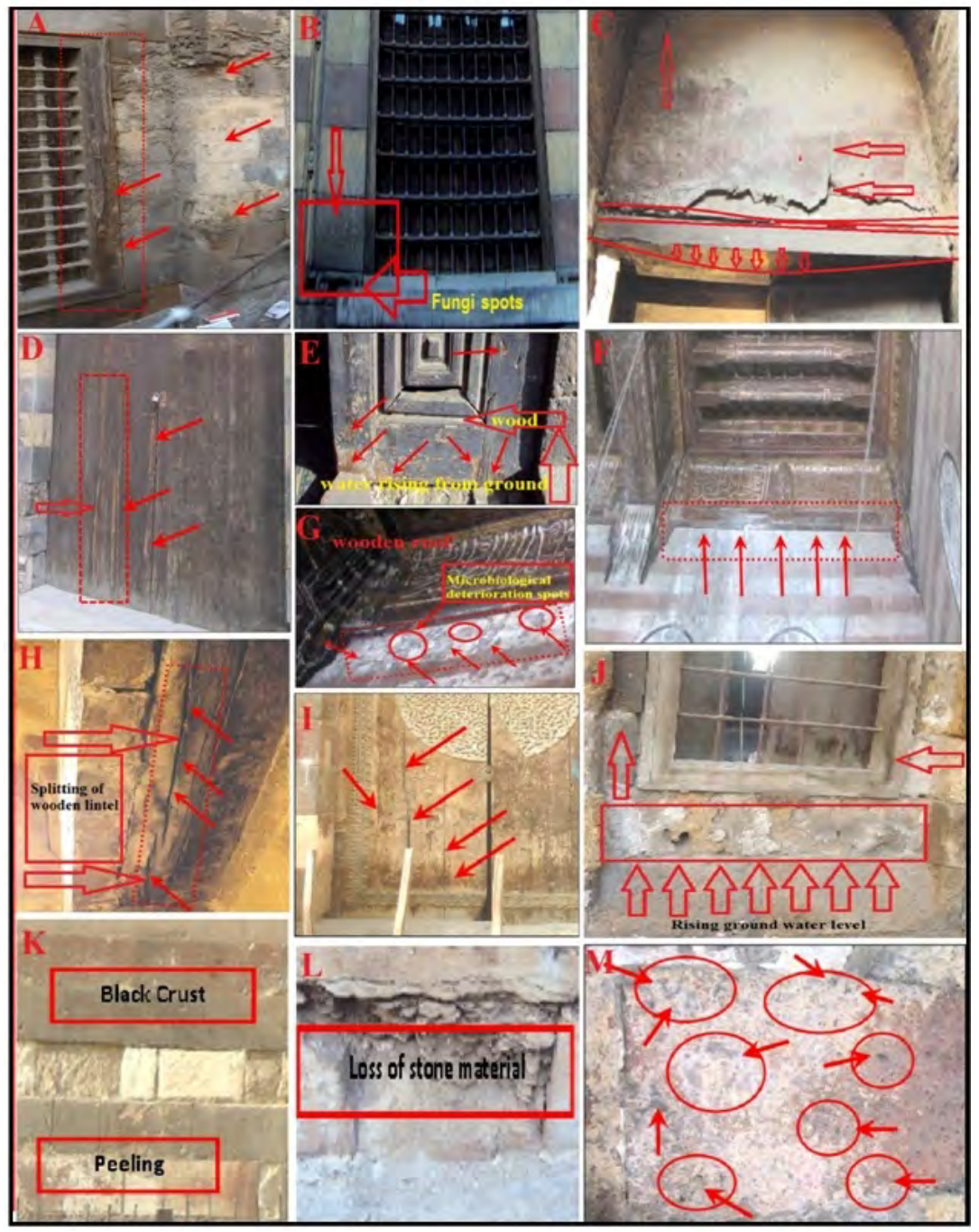

Figure 2. Deterioration features of limestone and wooden elements of a case studies : A-Loss of stone material and separation of wood texture, (Al maridani mosque), B-Fungi spots on limestone's surface (Madrasa of Qanibay alrammah), C- Deflection of wooden lintel due to fissures in wall, D-Cracking and flaking of paint layer of wooden door (Madrasa of Sultan Hassan), E-Flaking and crumbling of paint layer, F-Separation of wooden roof from wall (AlMahmoudia Mosque), G- Black spots on limestone surface, H- Splitting in the wooden lintel, I-Splitting in wooden door and the paint flakes with thick layers dropping off (Madrasa of Gawharal-Lala), J-Loss of stone material, and separation of wooden texture, K-Black crust and peeling , L-Loss of stone material, M- Pitting in limestone surface. 


\section{Methods and Materials}

The limestone and wood samples were collected from five archaeological sites in historic Cairo, The samples represented walls, windows, doors, wooden roofs. They generally consisted of damage layers.

\subsection{Building Materials characterization}

The stability of the building materials against weathering is strongly depends on their chemical, physical, mineralogical and petrographical properties (Zedef, et.al.\& Kekec, 2007). The Porosity is an important characteristic in the occurrence of limestone deterioration, the capillary properties of the stones is responsible for movement and absorption of water its inside (Weber, 2000).

The limestone is characterized by high porosity, in which that ranges from 5 to $20 \%$, and its density ranges from 2.2 to $2.5 \mathrm{~g} / \mathrm{cm}^{3}$, this porosity have ability to absorb the moisture from the air or ground, where due to penetration of salts into the components of stone, when crystallization of the soluble salts inside the pores of the stone, micro cracks occurs in the minerals crystals causes of internal pressure (Nakhla, 2004), the wood is characterized by low density, a specific weight range between 0.3 to $0.9 \mathrm{~g} / \mathrm{cm} 3$, and high porosity, so the shrinkage rate increases due to decrease of density where reach to $10 \%$ in the ancient wood. Moisture content in wood used in monumental buildings is about $20 \%$ (Abdullah, 2000).

\subsection{Polarizing Light Microscopy (PLM)}

The limestone samples were examined using ZEISS (Axio Imager. A1m) Polarized Light Microscopy (PLM), with an Axio Cam MRC5, under 20X magnification, thin section from deteriorated and not deteriorated samples were carried out in geology laboratory in the faculty of science, S.V. U, to study stratigraphy of the samples.

\subsection{Stereo Microscope}

The deteriorated and not deteriorated samples were observed using Olympus B X40 optical stereo microscope, and recorded with digital camera under 40-60X magnification to study their surface. The examination of samples were carried out in laboratories of the grand Egyptian museum.

\subsection{Scanning Electron Microscope}

The deteriorated and not deteriorated samples were investigated by SEM JEOL JSM 5500LV to identify morphology of the stone and used to examine the micro deterioration in the internal structure of limestone, also used to examine the wood element, sample s was coated with gold.

\subsection{Fourier Transform Infrared Microscopy (FTIR)}

Fourier Transform Infrared Microscopy (FTIR) was used to study the changes in wood chemistry compounds (cellulose-hemicellulose-lignin). FTIR spectra of wood samples were measured on a Nicolet 380 FT-IR Spectrometer, in the frequency range of $4000-400 \mathrm{~cm}^{-1}$, in transmission mode using the $\mathrm{KBr}$ pellet technique at the National Institute for Standards (NRC) in Cairo, Egypt.

\subsection{X-Ray Diffraction (XRD)}

X-ray diffraction method was carried out on deteriorated and not deteriorated limestone samples, to study the changes in mineral composition of the samples was performed in Micro Analytical Unit, faculty of archaeology, 
Cairo university, and was carried by X-ray diffraction patterns, using a Philips X-ray PW 1840 diffractometer with $\mathrm{Cu}-\mathrm{K} \alpha$ radiation generated at $40 \mathrm{kV}$ and $40 \mathrm{~mA}$. It covers $2 \Theta$ from 5o to 500. Mineral composition investigations were done by XRD for defining the chemical composition of limestone samples after the effect of weathering factors.

\subsection{Mechanical and physical properties tests}

Three samples of limestone for each build were cut into cubes of $5 \times 5 \times 5 \mathrm{~cm}$, the cubes were used to carry out the compressive strength test. Compressive strength carried out using a pressing machine. The pressure resistance (compressive strength) of each sample was calculated as follows in the equation (1). The physical properties (bulk density, water absorption and apparent porosity) of these samples were determined by calculating the volume of each sample, measuring the dry weight and the wet weight of each sample. The physical properties were calculated as follows, Bulk Density (d) in $\mathrm{g} / \mathrm{cm} 3$ was determined as follows in equation (2).

$$
\begin{gathered}
\text { Pressure Resistance }=F / A \\
\text { Bulk Density }(d)=M / V
\end{gathered}
$$

\subsection{Isolation and identification of fungi}

Fungi isolation was carried out in the laboratory after swabbing. The fungi were isolated by the swabs, czapek's media used as a dietary medium to isolate fungi which contain : 1-10 gm glucose, 2 gm sodium nitrate, 1 gm dihydrogen potassium phosphate, $0.5 \mathrm{gm}$ potassium chloride, $0.5 \mathrm{gm}$ magnesium sulphate, $0.25 \mathrm{gm}$ chloroamphenicol, $15 \mathrm{gm}$ agar, 1 liter water, $6.8 \mathrm{pH}$, Inoculated petri dishes were incubated at $25 \pm 2^{\circ} \mathrm{C}$ for $5-7$ days during which the developing fungi colonies were counted and identified.

After the incubation period, microscopic slides of these fungi were examined under optical microscopy. Morphological characteristics (color, shape and density of fungal colonies) were determined by their type, according to (Abdel - Hafez \& El Naggar, 2006).

\section{Results}

\subsection{Petrography study}

The examination of a thin section of limestone samples under polarized light microscope (PLM) that showing all samples are mainly consist of calcite, dolomite, and quartz, as secondary minerals, addition to clay minerals, fossils and iron oxides were found between grains, our observation that deteriorated samples are contained coarse grains of calcite, also found clay minerals, gypsum, iron oxides, between grains. The interstitial spaces in limestone texture fill with a fine mosaic texture of calcite crystals, as well as the presence of fragments of quartz crystals and various types of fossils, we conclusion that The presence of clay minerals, gypsum salt and iron oxides is facilitated from limestone weathering. 


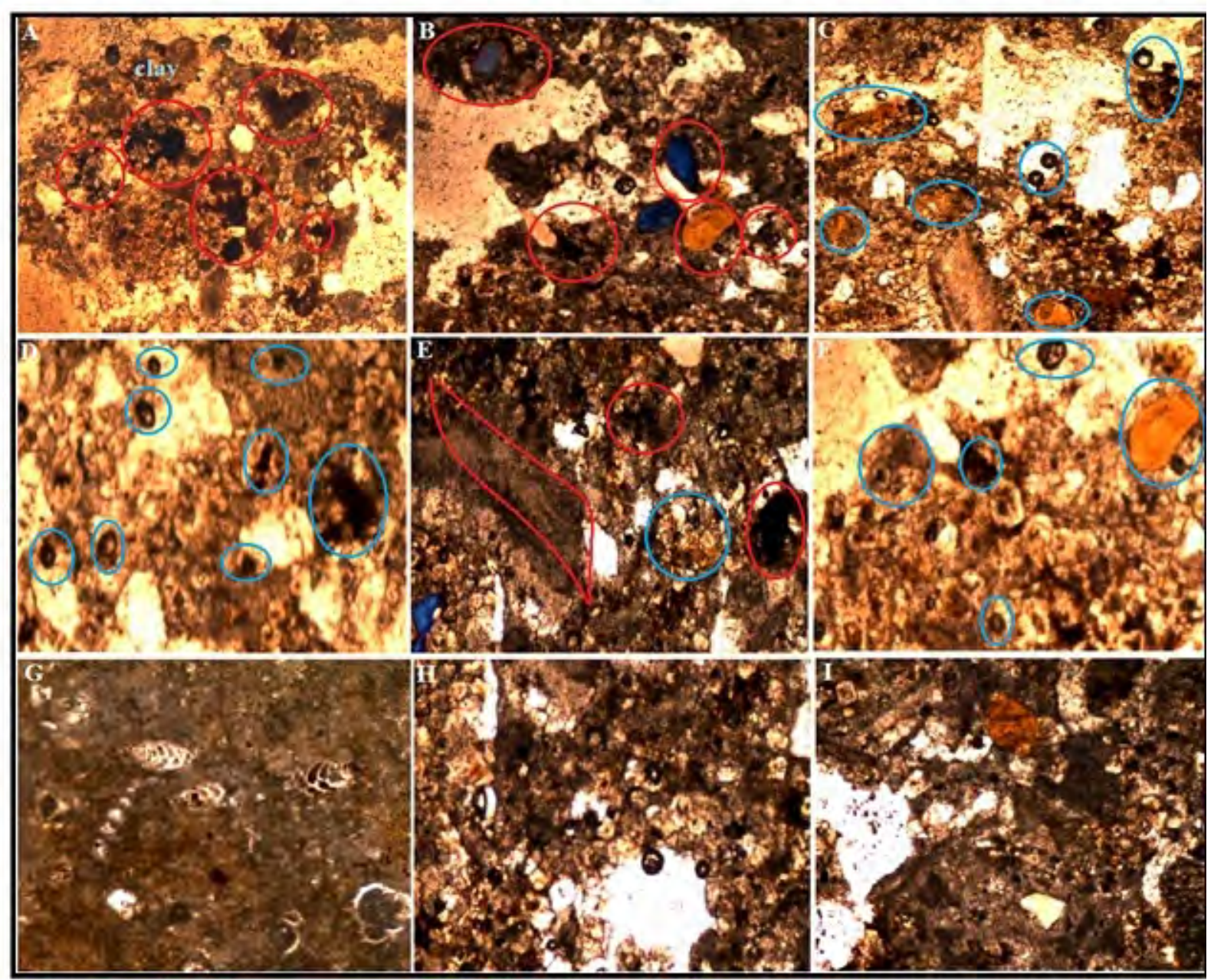

Figure 3. The examination of the limestone samples under polarized microscope shows: A- Showing an increase in porosity, clay minerals, iron oxides, and coarse grains of calcite in limestone texture (Al Mahmoudia Mosque), B- Thin section showing coarse grains of calcite, gypsum, cavities and iron oxides between grains (Al maridani mosque), C- showing high iron oxides between grains, clay minerals and cavities (Madrasa of Qanibay alrammah), D-Coarse grains of calcite, clay minerals and cavities (Madrasa of Sultan Hassan), E- High clay minerals, iron oxides, cavities, and coarse grain of calcite (Madrasa of Gawhar al-Lala), F- showing coarse grains of calcite, cavities and iron oxides between grains (Madrasa of Sultan Hassan). G-I- Different kinds of fossils, fine grains of calcite and little cavities.

\subsection{Stereo Microscope}

Results from the samples studied using Stereo Microscope are presented in (Figure 4)

Limestone samples are investigated by Stereo Microscope, showing roughening and soiling in limestone surface, addition to Granular disintegration and accumulation of dust and salt particles on stone surface (Figure 4 A, B, C). Wood samples which investigated, show ing accumulation of dust between wood fibers, addition to separation of fibers due to the effect of moisture, and crystalline salts was found between fibers (Figure 4 D, E, F). 


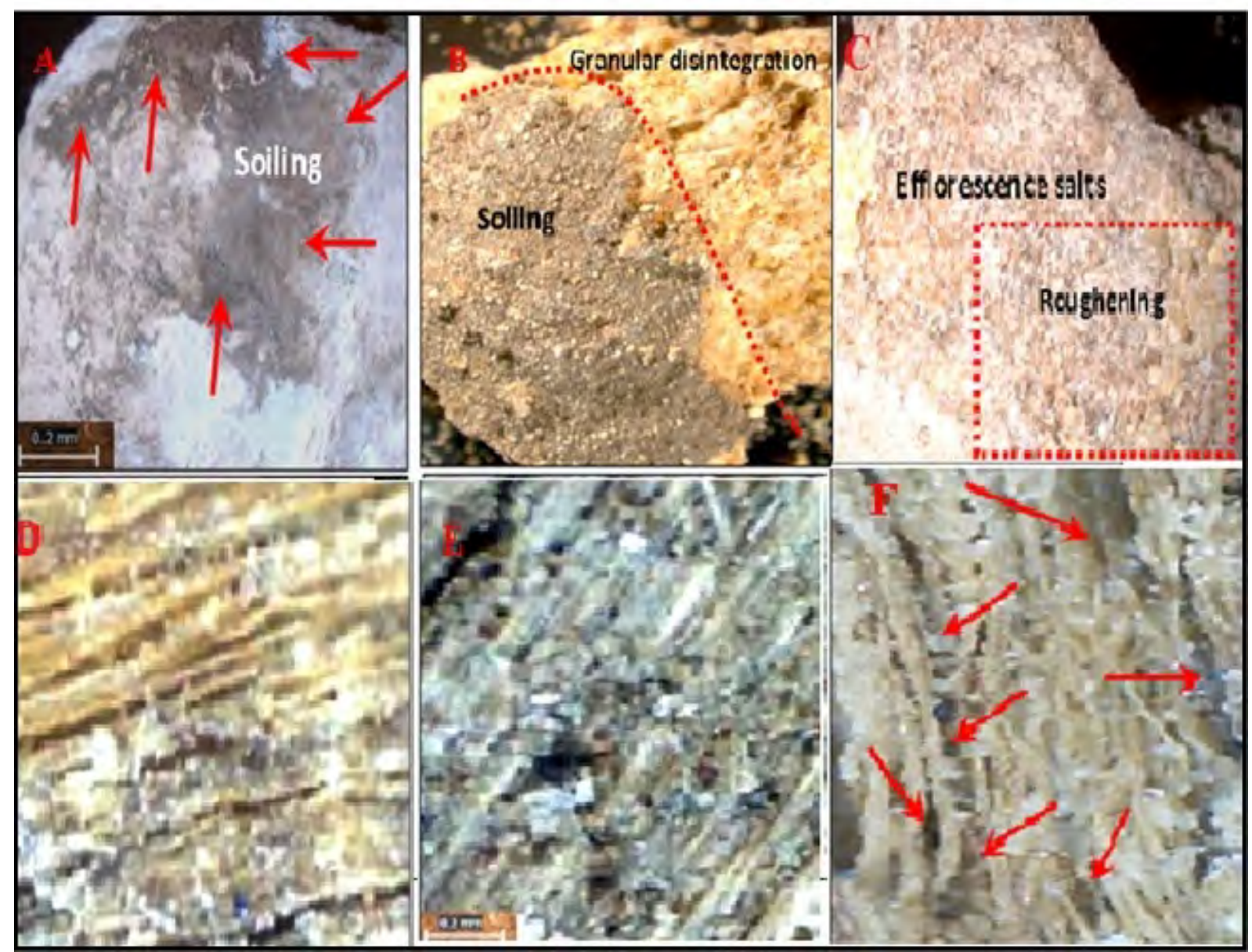

Figure 4. StereoPhotomicrographs of stones and woods. A-Showing roughening and soiling in limestone surface (Madrasa of Sultan Hassan), B- Granular disintegration and accumulation of dust and salt particles on the limestone surface (Al Mahmoudia Mosque), C-Efflorescence salts and roughening with limestone surface (Al maridani mosque), D-Accumulation of salts crystals between wood fibers addition to separation of fibers (Al maridani mosque), E- Separation of wood fiber and found crystalline salts between fibers (Madrasa of Qanibay alrammah), F- showing damage of wooden fibers and crystalline salts was found between fibers (Madrasa of Gawhar al-Lala).

\subsection{SEM - EDX investigation}

Results from the limestone samples studied using SEM are presented in (Figure 5)

SEM image of limestone samples show ed disintegration between calcite crystals and dense of halite and gypsum crystals which covers the pores of the stone, addition to loss of binding materials, and there is fungal hyphae penetrated mineral crystals of limestone. (Figure 5 A, B, F).

Deterioration and corrosion observed in calcite crystals, loss of the binding materials, we observed an increase in the size of stone pores, micro cracks, loss in Internal Structure result of internal stresses between the mineral crystals due to re-crystallization of the salt inside stone pores, addition to fungal infection was observed (Figure 5 $\mathrm{D}, \mathrm{E}, \mathrm{F})$.

The EDX analytical methods were performed to identify the deteriorated samples of limestone to evaluate their different components. The investigation results are shown in (Table 1) and (Figure 7). An EDX micro analysis of the samples indicated that there are elements found in deteriorated samples were caused accelerating weathering of the limestone according to their concentration in the stone as follows: the deteriorated samples contain of increase in the following elements' concentration : $\mathrm{Na}(6.4 \%), \mathrm{Mg}(2.16 \%), \mathrm{Si}(6.05 \%), \mathrm{Cl}(8.0 \%), \mathrm{Al}(1.27 \%), \mathrm{Fe}$ 
(4.57\%), these elements was evidence in finding halite salts, clay minerals and iron oxides in which deterioration the limestone more than the limestone samples contains of decrease in the previous elements' concentration.

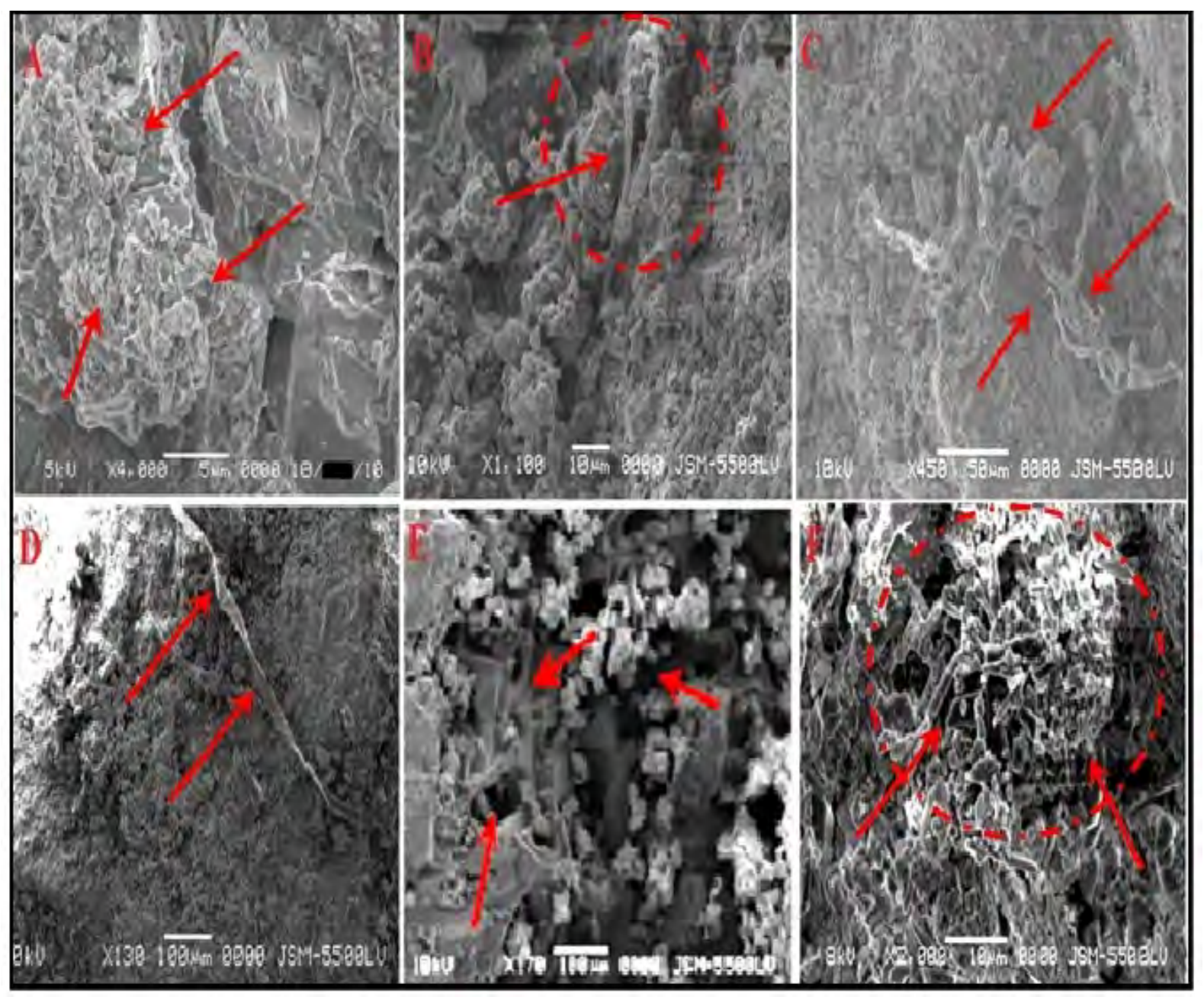

Figure 5. SEMPhotographs of limestone and woods. A-Showingthe deterioration of mineral crystals and crystalline salts and loss of bindingmaterials (4000X), B- Showing damage of calcitecrystals and loss of bonding materials addition to found fungi infectionbetween grains (1100X), C- fungi between minerals crystals of limestone(450X), D-fungal hyphae inside mineral crystalsand found disintegration of grains (130X), E-loss of bonding materials and corrosion of mineral crystals (170X), FDeterioration of mineral crystals and loss ofbonding materials, fungal hyphae is found between the minerals crystals(2000X).

\subsubsection{Results from the wood samples studied using SEM are presented in (Figure 6)}

SEM image of the wood samples showed Damage to cells and Crystallization of Salts between wood fibers, the examination is shown damage to wood fibers, also an observation detachment of anatomical elements and Fungal hyphae is penetrated wood fibers (Figure $6 \mathrm{~A}, \mathrm{~B}, \mathrm{D}, \mathrm{E}$ ). Loss of wooden fibers was observed using SEM examination and Separation of wood cells (Figure 6 C, F, G, H, I). 


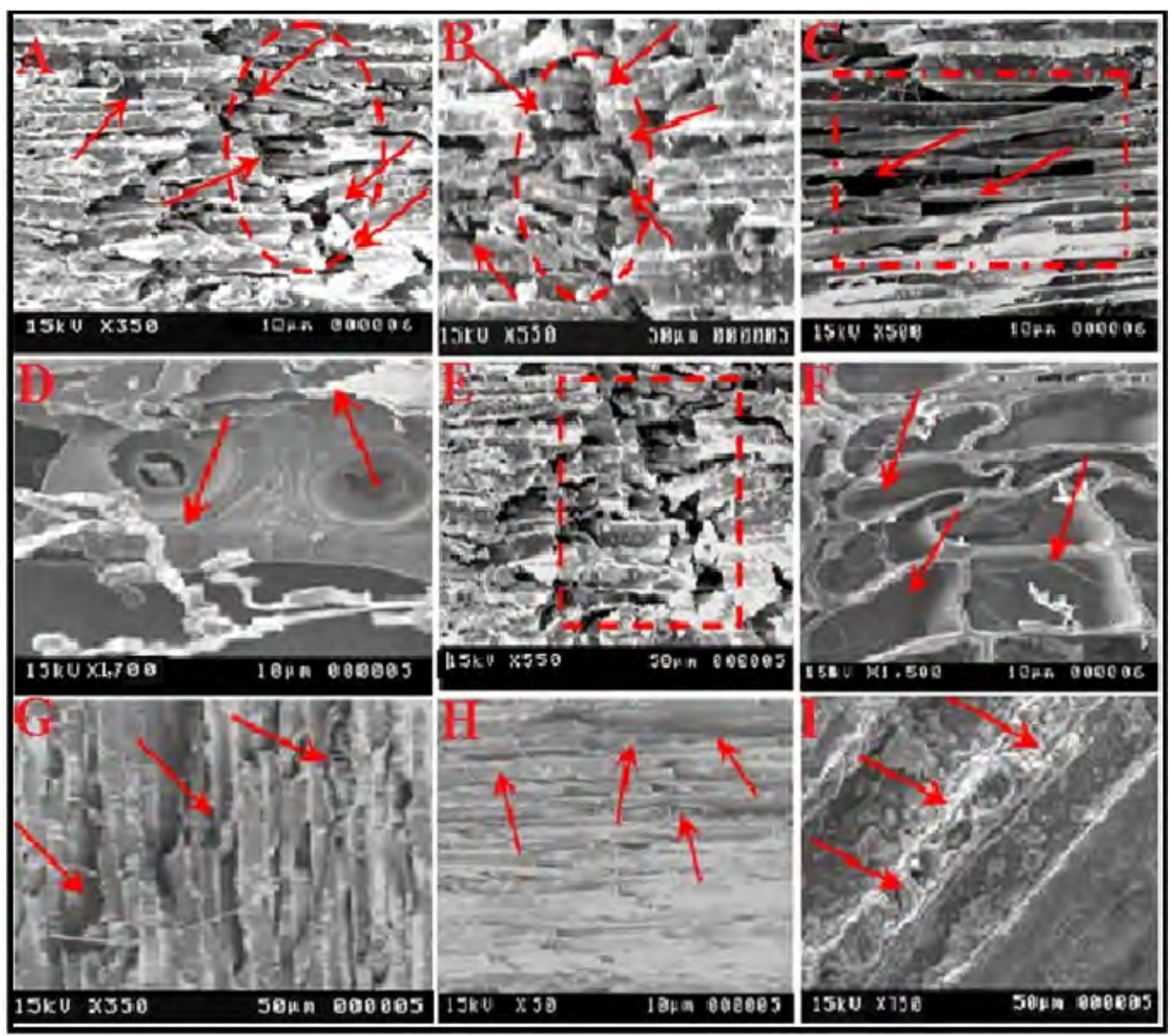

Figure 6. SEM Photographs of woods. A-Damage of wood cells and Crystallization of Salts between wood fibers (350X), B-

Destroyed wood fibers show from examination (550X), C- Detachment of anatomical elements D- Fungal hyphae is

penetrated wood fibers and crystallization of salt between fibers (1700X), E-Damage of wood fibers and a detachment of anatomical elements (fibers) (550X), F- Crystallization of Salts between wood fibers (1500X), G- Separation of wooden fibers, loss of wooden fibers and destroyed of cells (350X), H-Separation of wood cells (50X), I- Damage to cells and loss of wooden fibers due to re-crystallization of salts in fibers (150X).

\subsection{Mineralogical study using $X-$ Ray diffraction (XRD)}

The limestone samples analysis were carried out by XRD for defining the different mineral components of samples. All results are shown in (table 2) and (Figure 8). The results of the study show that the deteriorated limestone samples consists of calcite $\left(\mathrm{CaCO}_{3}\right)$, dolomite $\left(\mathrm{Ca}, \mathrm{Mg}\left(\mathrm{CO}_{3}\right)_{2}\right)$, as a major minerals, addition to quartz $\left(\mathrm{SiO}_{2}\right)$, kaolinite $\left(\mathrm{Al}_{2}(\mathrm{OH}) 4 \mathrm{Si} 2 \mathrm{O} 5\right)$, montmorillonite $\left.(\mathrm{Na}, \mathrm{Ca}) 0.33(\mathrm{Al}, \mathrm{Mg})_{2}(\mathrm{Si} 4 \mathrm{O} 10)(\mathrm{OH})_{2} \cdot \mathrm{nH}_{2} \mathrm{O}_{2} \mathrm{Si}_{4} \mathrm{O}_{10}(\mathrm{OH})_{2}\right)$, orthoclase (KAlSi3O8), as a minor minerals and halite $(\mathrm{NaCl})$, gypsum( $\mathrm{CaSO} 4.2 \mathrm{H} 2 \mathrm{O})$, anhydrite $(\mathrm{CaSO} 4)$ hematite $\left(\mathrm{Fe}_{2} \mathrm{O}_{3}\right)$.

These results revealed the presence of clay minerals, minerals salts and iron oxides, in which accelerated of limestone weathering, due to that the soluble chloride and sulphate addition to clay minerals much damage to the porous materials such as limestone. Because these components absorb moisture easily from the atmosphere and 
thus increase the moisture content within the stone, which dissolves the salts in the pores, and when evaporation of water occurs crystallization and re - crystallization of salts causing mechanical damage to the stones due to crystallization and re-crystallization pressure.

Table 1. Samples quantitative EDX analysis of the limestone samples

\begin{tabular}{|c|c|c|c|c|c|c|c|c|}
\hline Samples & $\mathrm{Na}$ & $\mathrm{Mg}$ & $\mathrm{Al}$ & $\mathrm{Si}$ & $\mathrm{Cl}$ & $\mathrm{K}$ & $\mathrm{Ca}$ & $\mathrm{Fe}$ \\
\hline $\mathrm{A} 1$ & 7.08 & 2.63 & 1.24 & 6.44 & 8.71 & 0.84 & 66.09 & 4.62 \\
$\mathrm{~A} 2$ & 4.87 & 1.27 & 1.23 & 6.28 & 6.57 & 1.30 & 61.69 & 3.47 \\
$\mathrm{~A} 3$ & 7.23 & 2.60 & 1.34 & 5.44 & 8.70 & 2.81 & 66.08 & 5.62 \\
$\mathrm{~A} 4$ & - & - & 1.66 & 2.32 & & & \\
A5 & 1.36 & 0.80 & 1.74 & 5.48 & 1.64 & & 90.26 & 0.67 \\
\end{tabular}

Table 2. Mineralogical composition of the limestone samples

\begin{tabular}{|c|c|c|c|c|c|c|c|c|c|}
\hline Samples & Calcite & Dolomit & Quartz & Halite & Gypsum & Kaolinite & Hematite & \multicolumn{2}{|c|}{ Montmorillidmihydrit } \\
\hline A & 60 & $\longrightarrow$ & 8 & 14 & 10 & 8 & - & - & - \\
\hline $\mathrm{B}$ & 40 & 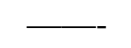 & 20 & 15 & 14 & 3 & 6 & $\longrightarrow$ & - \\
\hline $\mathrm{C}$ & 94 & & - & 3 & $\ldots$ & - & 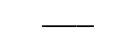 & - & 2 \\
\hline $\mathrm{D}$ & 50 & 32 & 4 & 7 & 2 & 2 & 2 & - & - \\
\hline $\mathrm{E}$ & 70 & - & - & 25 & - & 4 & - & - & - \\
\hline
\end{tabular}

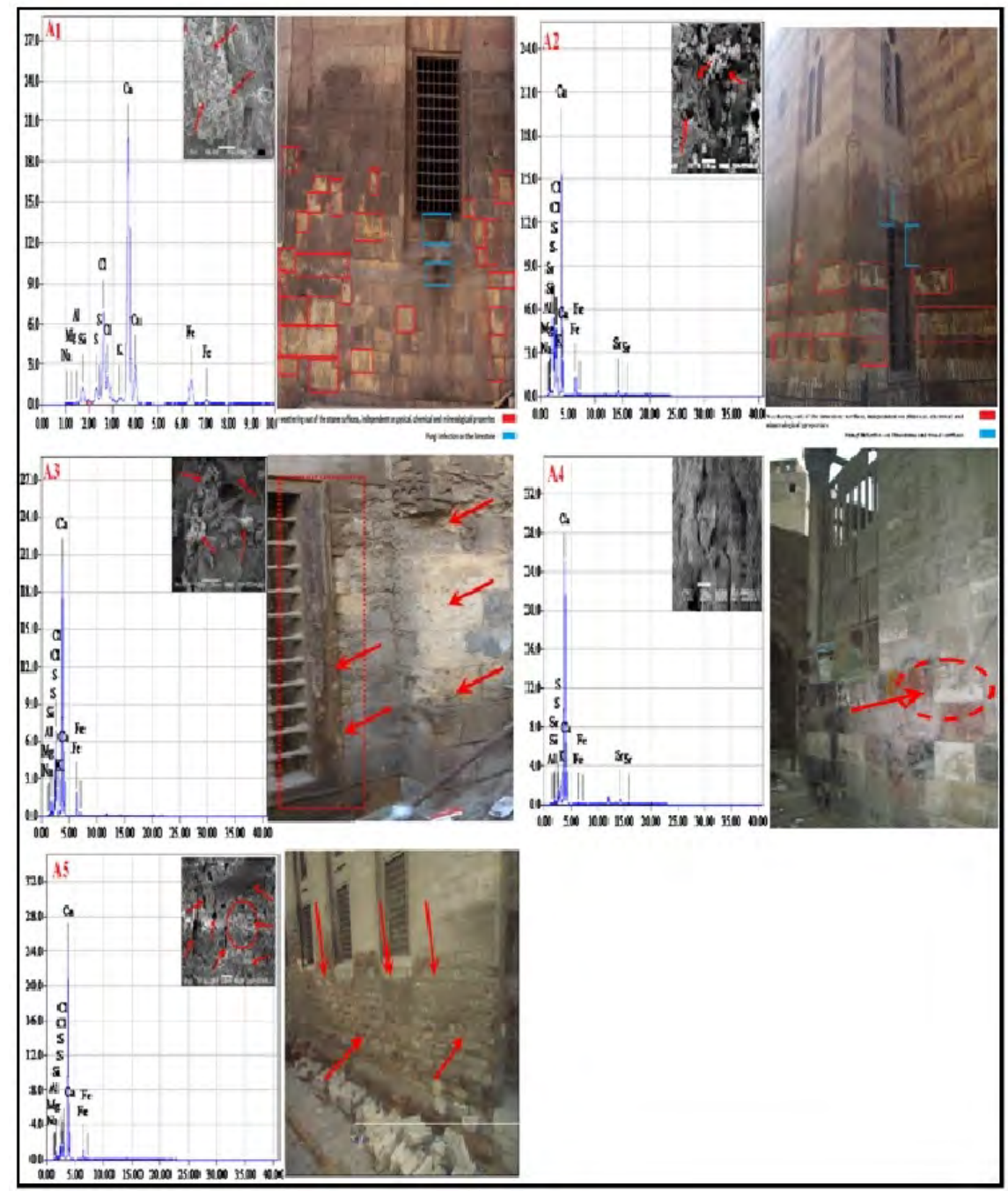

Figure 7. EDX analysis pattern of the limestone samples : A1- Al Mahmoudia Mosque, A2-Madrasa of Qanibay alrammah, A3- Al maridani mosque, A4- Madrasa of Gawhar al-Lala, A5- Madrasa of Sultan Hassan 


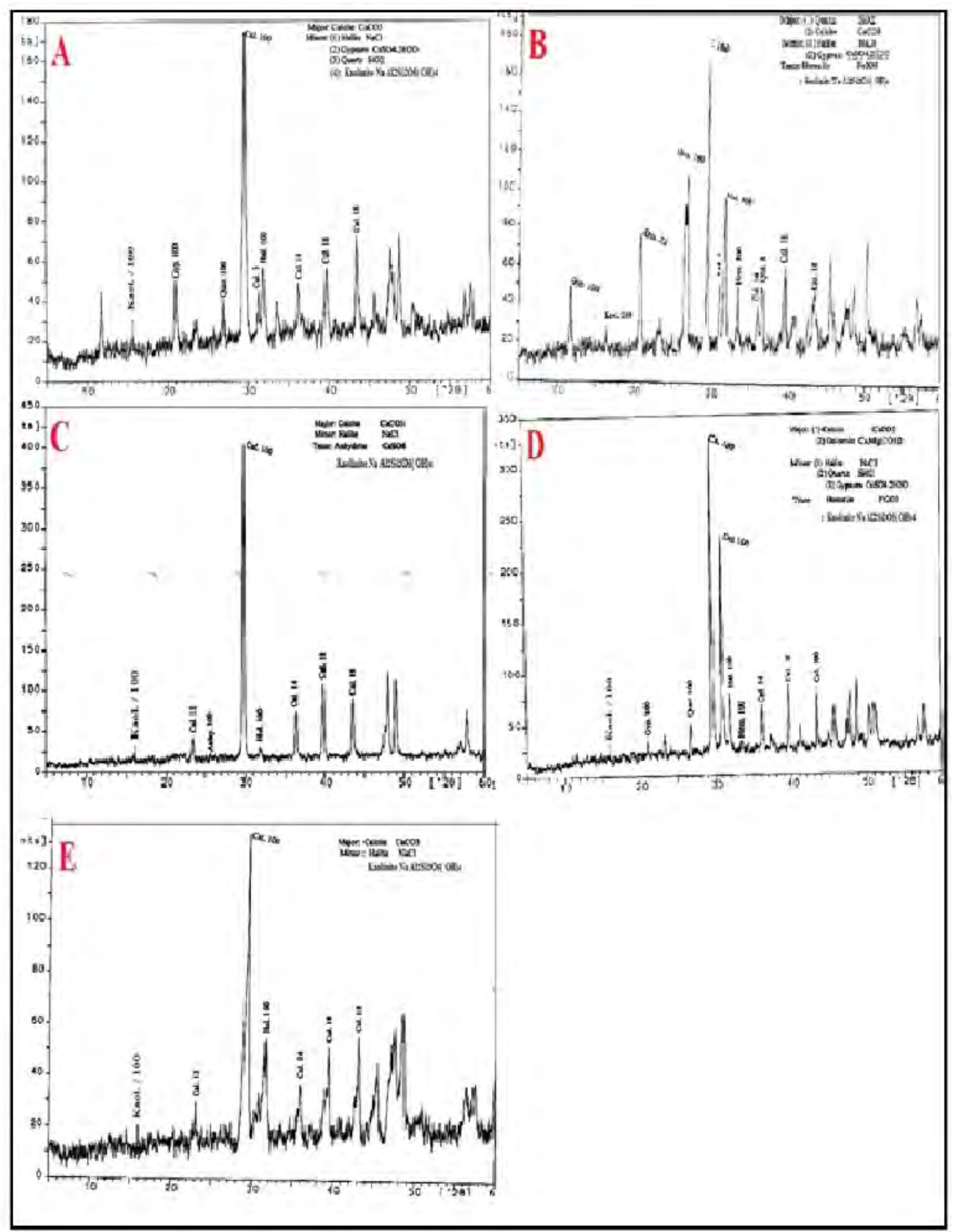

Figure 8. XRD pattern of the limestone samples presented case studies sites. 


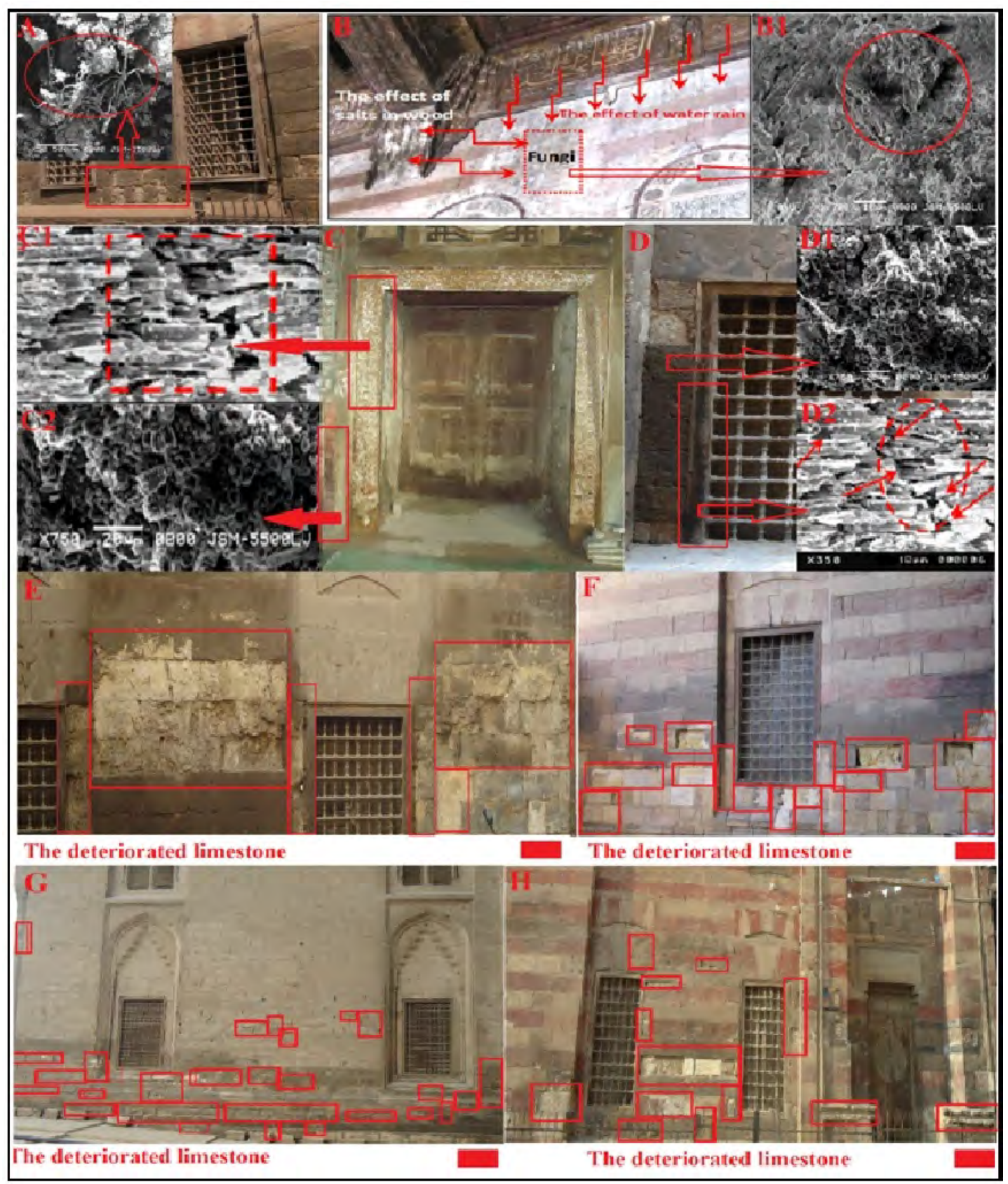

Figure 9. Deterioration features of limestone and wooden elements of a case studies : A- SEM image is shown fungal infection on limestone surface close to the wooden elements (Madrasa of Qanibay alrammah), accumulation of dust and salt particles in wooden texture (Al maridani mosque), B- Fungi spots in limestone surface and the efflorescence of wooden surface, due to the reciprocal relations of damage, B1- SEM image is shown fungi hyphae in mineral crystals of limestone (AlMahmoudia Mosque), C- C1- SEM image is shown the effect of salts weathering in degradation of wooden elements, due to its adjacent to limestone, C2- SEM image is shown the effect of fungal damage in limestone (Al maridani mosque). And

Deflection of wooden lintel due to fissures in wall (Madrasa of Qanibay alrammah), D- (D1, D2) The same previous explanation. E-H damage of limestone independent on the difference of its properties (Al Mahmoudia Mosque, Al maridani mosque, Madrasa of SultanHassan, Madrasa of Gawhar al-Lala). 


\subsection{Fourier Transform Infrared Microscopy (FTIR)}

$\mathrm{T}$ he wave number and functional groups of wooden bands are shown (Table,3), in which used for comparison between the different wooden samples.

The results of FTIR analysis of the deteriorated wood samples are shown in (Figure 9,10) that most changes occurred in the chemical compounds in the area around (3 $422-850 \mathrm{~cm}-1)$, such as Decrease of the intensity band of $\mathrm{C}=\mathrm{O}=\mathrm{C}$ stretching around $(1156 \mathrm{~cm}-1)$, due to breaking of cellulose chains and the occurrence of depolymerisation.

Decrease of $\mathrm{C}=\mathrm{C}$ stretching band around $(1520 \mathrm{~cm} \mathrm{-1)}$ due to loss of lignin, due to fungal degradation, also FTIR analysis shown decrease of the intensity band of unconjugated $\mathrm{C}=\mathrm{O}$ stretching around $(1790 \mathrm{~cm}-1)$ due to the decrease in the hemicellulose amount of the deteriorated samples (according to, Zidan, et.al.2016). Decrease of $\mathrm{O}-\mathrm{H}$ stretching around $(3422 \mathrm{~cm}-1)$, by the decrease in Cellulose, Lignin and hemicelluloses amount.

From the previous results, revealed that a 11 wood samples present adjacent to the stones have been changed in the chemical compounds, due to increase its content moisture and effect salt weathering.(Figure $6 \&$ Table 4)

Table 3. The wave numbers and Functional groups of wood as a standard

\begin{tabular}{|c|c|c|}
\hline $\begin{array}{c}\text { Wave number } \\
(\mathrm{cm}-1)\end{array}$ & Functional group & Assignment \\
\hline 3400 & O-H & O-H stretching \\
$2970-2850$ & C-H stretching \\
$1738-1735$ & C = O stretching in unconjugated ketones \\
aldehydes and carboxyl & Xylan and hemicellulose \\
1650 & absorbed O-H and conjugated C-O & \\
$1605-1595$ & C=C stretching of the aromatic ring & Lignin \\
1512 & C=C stretching of the aromatic ring & Lignin \\
1463 & Asymmetric bending in CH3 & Lignin \\
1425 & CH2 bending & amorphous) \\
1375 & CH bending & Cellulose \\
1336 & OH in plane bending & Cellulose (crystallized and \\
1317 & CH2 wagging & CO stretching \\
1163 & C-O-C bridge oxygen stretching & Cellulose (crystallized I) \\
897 & Asymmetric. Out of phase ring stretching & Lignin and hemicellulose \\
\hline
\end{tabular}

Table 4. The wave numbers and Functional groups of the deteriorated wood samples

\begin{tabular}{|c|c|c|}
\hline Wave number $(\mathrm{cm}-1)$ & Functional group & Assignment \\
\hline 3422 & O-H stretching & $\begin{array}{l}\text { Cellulose, Lignin and } \\
\text { hemicellulose }\end{array}$ \\
\hline 2926 & C-H 2 asymmetric stretching & $\begin{array}{l}\text { Cellulose, Lignin and } \\
\text { hemicellulose }\end{array}$ \\
\hline 1790 & $\begin{array}{c}\mathrm{C}=\mathrm{O} \text { stretching in unconjugated ketones } \\
\text { aldehydes and carboxyl }\end{array}$ & Xylan and hemicellulose \\
\hline 1520 & $\mathrm{C}=\mathrm{C}$ stretching of the aromatic ring & Lignin \\
\hline 1163 & COC Asymmetric. bridge oxygen stretching & Cellulose \\
\hline 897 & $\begin{array}{l}\mathrm{C}-\mathrm{H} \text { aromatic bending out of plan }+\mathrm{C}-\mathrm{H} \\
\text { rocking }\end{array}$ & Lignin + cellulose \\
\hline
\end{tabular}




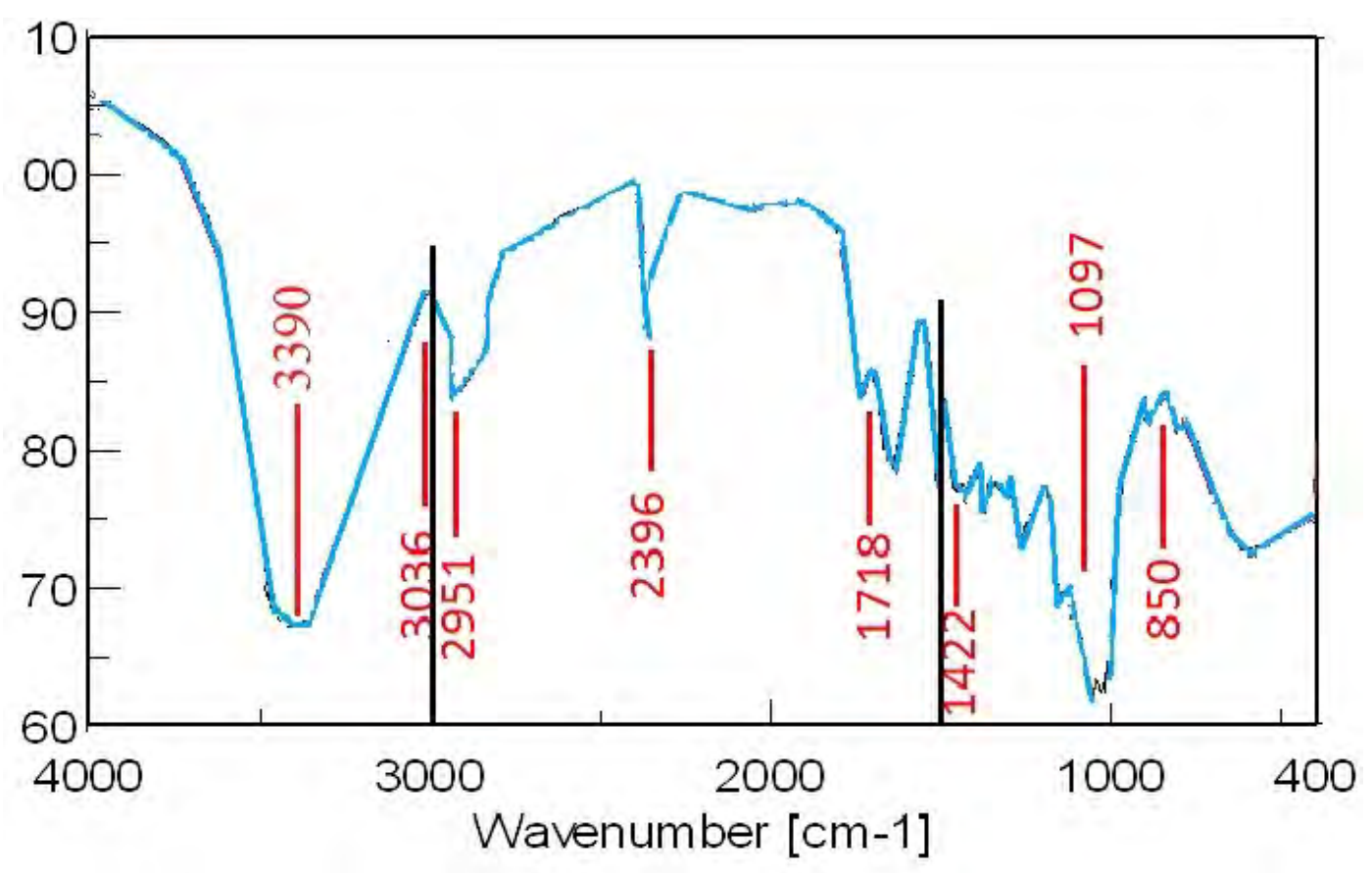

Figure 10. FTIR Spectra Transmittance of the deteriorated wooden samples

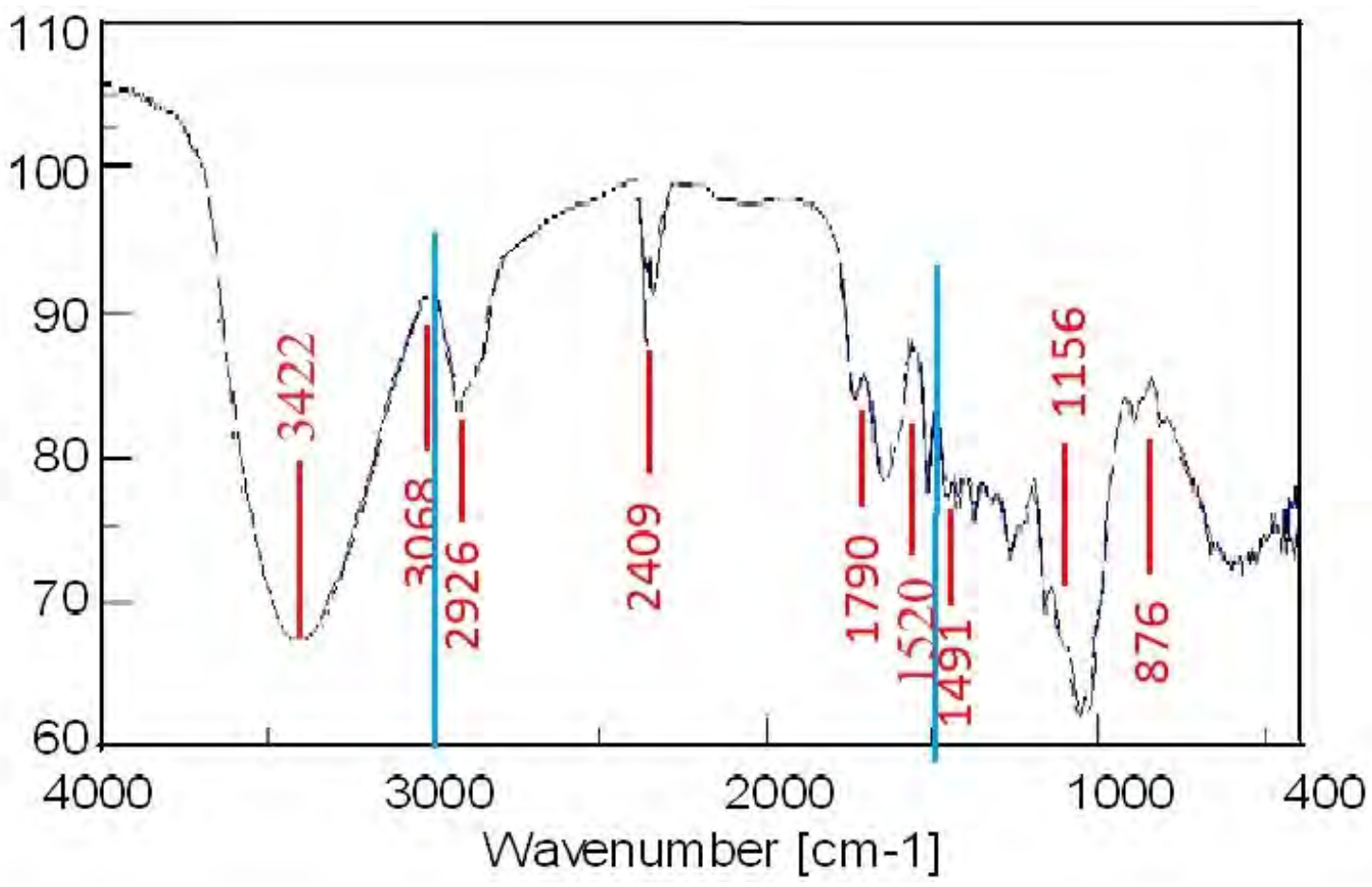

Figure 11. FTIR Spectra Transmittance of the deteriorated wooden samples

\subsection{Results of mechanical and physical properties tests}

The results of physical properties tests of the deteriorated limestone samples are shown in (Table 5), which explain that increase in porosity, water absorption and decrease in density of samples, in particular the limestone samples which were contained on high concentrations of mineral salts, clay minerals and iron oxides. Also all the deteriorated samples have been decreasing in its mechanical properties (Table 6) 
Mohamed / Proceedings of Science and Technology

Table 5. Physical properties tests of the limestone samples

\begin{tabular}{|c|c|c|c|}
\hline \multirow{2}{*}{ Sampels } & \multicolumn{2}{|c|}{$\begin{array}{c}\text { Physical properties } \\
\text { Porosity vol.\% }\end{array}$} \\
A1 & Water absorption wt.\% & 15.65 & 2.27 \\
A2 & 8.64 & 17.12 & 1.98 \\
A3 & 9.75 & 16.21 & 2.18 \\
A4 & 8.83 & 19.88 & 1.73 \\
A5 & 10.54 & 16.81 & 1.54 \\
A6 & 9.57 & 15.35 & 2.09 \\
\hline
\end{tabular}

Table 6. Mechanical properties tests of the limestone samples

\begin{tabular}{|c|c|c|}
\hline \multirow{2}{*}{ Sampels } & \multicolumn{2}{|c|}{ Physical properties } \\
& Compressive Strength & Tensile strength k.gm / m2 \\
k.gm / m2 & 62 \\
A2 & 164 & 58 \\
A3 & 143 & 63 \\
A4 & 162 & 54 \\
A5 & 134 & 57 \\
A6 & 138 & 60 \\
\hline
\end{tabular}

\subsection{Results of microbiological study}

The limestone and wood Samples were investigated by (SEM), the examination was shown evidence of microbiological attack. Isolated fungi were found in various parts of limestone and wood used in archaeological sites (case studies), six fungal species were isolated from infection samples, showing following : Aspergillus flavus, Aspergillus terreus, Aspergillus niger, Aspergillus fumigatus, Clado Sporium, Saccharomyces (Figure 10, A-F).

We observed that all limestone samples which found adjacent to the wooden elements used in the buildings (case studies) were the most infected with fungal infection, due to that wood as an organic material i s one the most of the factors that help the growth of fungi.

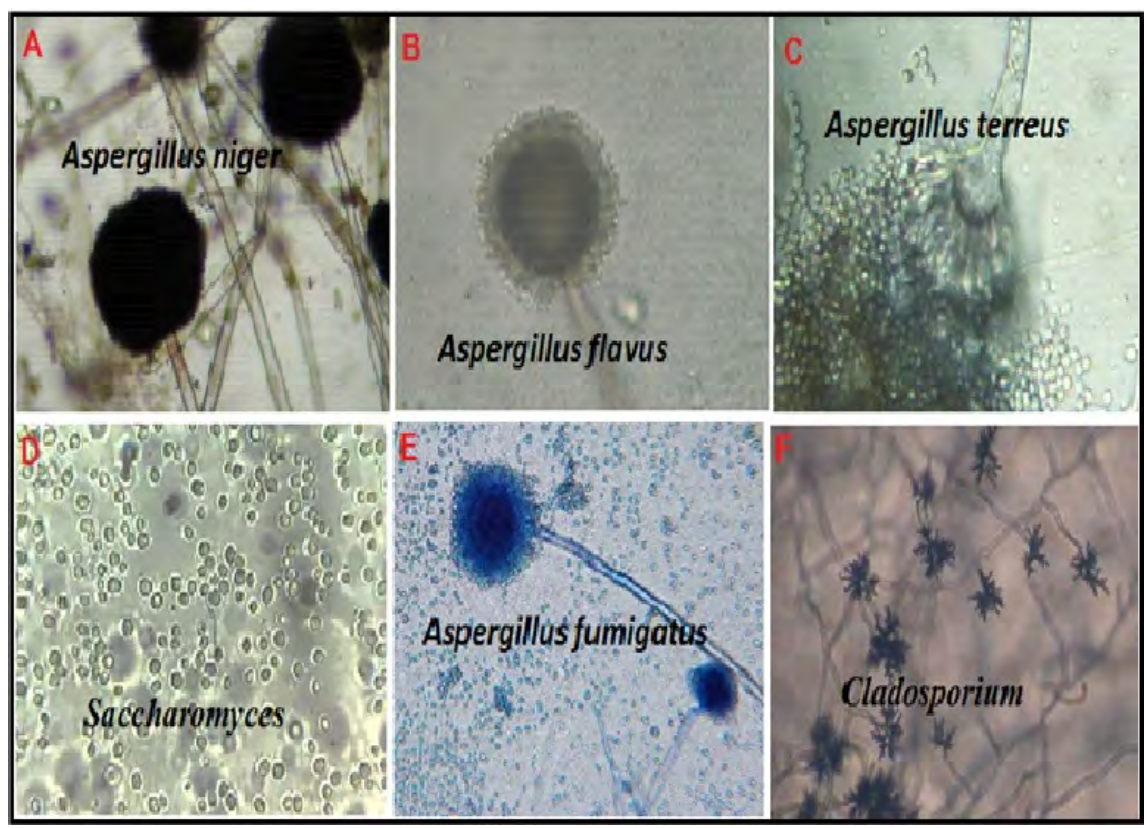

Figure 12. Microscope photographs of isolated fungi from surfaces of the limestone and wooden elements 


\section{Conclusions}

The investigation methods were carried out by several scientific techniques on sample s of different building materials (limestone - wood) used in case studies, indicated that the physical, chemical and mechanical properties of building materials (limestone - wood) play the main role with the surrounding environment factors in the weathering mechanism and deterioration phenomena they present.

The effect of the reciprocal relations of the deterioration symptoms in different building materials in some of historic Cairo's buildings were shown in the following :

From in-situ observation, we can notice that there is varying in forms and intensity of limestone weathering used in case studies, due to the difference in stone properties (Figure 11). The results of XRD and SEM- EDX revealed that the deteriorated limestone samples contains of increase in the following elements' concentration : $\mathrm{Na}(6.4 \%), \mathrm{Mg}$ (2.16\%), Si (6.05\%), $\mathrm{Cl}(8.0 \%), \mathrm{Al}(1.27 \%), \mathrm{Fe}(4.57 \%)$, these elements were evidence on found halite, gypsum salts, clay minerals and iron oxides, presence of the high concentrations of these components led to accelerating damage to limestone (Table 1,2).

The results of physical properties of limestone samples were indicated increase in porosity, water absorption and decrease in density of samples, in particular the limestone samples which were contained on high concentrations of mineral salts, clay minerals and iron oxides. Also all the deteriorated samples have been decreasing in its mechanical properties (Table 5,6).

From FTIR analysis, we are observing that all wooden samples present adjacent to the stones have been changed in the chemical compounds, due to increase its content moisture and effect salt weathering.(Figure 6 Table 4), also all limestone samples which found adjacent to the wooden elements were the most infected with fungal infection, due to that wood as an organic material i s one the most of the factors that help the growth of fungi (Figure 9).

From discussion of the previous results, we can explanation of varying in forms and intensity of weathering of building materials, which is due to the difference of its properties and the reciprocal relations of deterioration symptoms.

\section{A. References}

1. Abd Elhady, M.(1995). Ground water and the deterioration of Islamic building in Egypt, in the conference of (the restoration and conservation of Is lamic monuments in Egypt), AUC, p.118

2. Abd Elhady, M. (1997). Scientific studies in restoration and conservation of inorganic monuments, zahra el shark library, 1997

3. Abdullah, I. (2000). A study of treatment, conservation and decorative elements in some archeological buildings in rashid, Thesis of Doctor, monuments conservation Dept., faculty of archaeology, Cairo university, P.p.147-148

4. Abdel - Hafez, S. I. I., \& El Naggar, S. M. (2006). Morphological, reproductive and mycobiota characters of three wild medicinal plants inhabiting Western Mediterranean coastal land, Egypt. Feddes Repertorium: Zeitschrift für botanische Taxomonie und Geobotanik, 117(3 - 4), 240-249.

5. Collepardi, M. (1990). Degradation and restoration of masonry walls of historical buildings. Materials and structures, 23(2), 81-102.

6. Charola, A. E. (2000). Salts in the deterioration of porous materials: an overview. Journal of the American institute for conservation, 39(3), 327-343.

7. Eriksson, K. E. L., Blanchette, R. A., \& Ander, P. (2012). Microbial and enzymatic degradation of wood and wood components. Springer Science \& Business Media. 
8. Fassina, V.(1991 ). Pollution atmospherique et alteration de la pierre, La degradation et la conservation de la pierre, p 91 .

9. George, B., Suttie, E., Merlin, A., \& Deglise, X. (2005). Photodegradation and photostabilisation of wood-the state of the art. Polymer Degradation and Stability, 88(2), 268-274.

10. Grossi, C. M., \& Brimblecombe, P. (2007). Effect of long-term changes in air pollution and climate on the decay and blackening of European stone buildings. Geological Society, London, Special Publications, 271(1), 117-130.

11. Gupta, S. P., \& Sharma, K. (2012). The role of fungi in bio deterioration of sandstone with reference to Mahadev temple, Bastar, Chhatisgarh. Recent Research in Science and Technology, 4(3), 18-21.

12. Hamid, A. A. (2006). Durability of historic brick masonry, Proceedings of the First International Conference on Restoration of Heritage Masonry Structures : Cairo, Egypt, April 24-27, P 3.

13. Honeyborne, D. (1990). Weathering and Decay of Masonry, " conservation of building and decorative stone ”, vol 2, London vol. 1. P 153

14. Hemeda, S., Khalil, M., Shoeb, A., \& EL AZIZ, A. A. (2018). THE EFFECTIVENESS OF NANO MATERIALS AND NANOMODIFIED POLYMERS FOR PRESERVATION OF HISTORIC BRICK MASONRY IN RASHID, EGYPT. International Journal of Conservation Science, 9(4), www.ijcs.uaic.ro

15. Ismail, B.(2003) Geotchenical studies of the Rock Tombs of Tel el Amarna, Egypt, Fayum conf., faculty of Archaeology, Fayum Branch, Cairo University.

16. Jain, A., Bhadauria, S., Kumar, V., \& Chauhan, R. S. (2009). Biodeterioration of sandstone under the influence of different humidity levels in laboratory conditions. Building and Environment, 44(6), 1276-1 284.

17. Lionetto, F., Del Sole, R., Cannoletta, D., Vasapollo, G., \& Maffezzoli, A. (2012). Monitoring wood degradation during weathering by cellulose crystalline. Materials, 5(10), 1910-1922. www.mdpi.com/journal/ma terials.

18. Nakhla, F.(2004). engineering geology, $9^{\text {th }}$ edition, dar elmaarf, p.81.

19. Přikryl, R., \& Smith, B. J. (Eds.). (2007). Building stone decay: from diagnosis to conservation. Geological Society of London.

20. Scheme, G.(2000). Stress from Crystallization of salts in pores,. On deterioration and conservation of stone, 9th inter conference, Cong, Venice, pp. 187-195.

21. Weber, H., \& Zinsmeister, K. (1991). Conservation of natural stone: guidelines to consolidation, restoration, and preservation.

22. Xie, Y., Krause, A., Mai, C., Militz, H., Richter, K., Urban, K., \& Evans, P. D. (2005). Weathering of wood modified with the N-methylol compound 1, 3-dimethylol-4, 5-dihydroxyethyleneurea. Polymer Degradation and Stability, 89(2), 189-199.

23. Zedef, V., Kocak, K., Doyen, A., Ozsen, H., \& Kekec, B. (2007). Effect of salt crystallization on stones of historical buildings and monuments, Konya, Central Turkey. Building and environment, 42(3), 1453-1457.

24. Zidan, Y., El Hadidi, N. N., \& Mohamed, M. F. (2016). EXAMINATION AND ANALYSES OF A WOODEN FACE AT THE MUSEUM STORAGE AT THE FACULTY OF ARCHAEOLOGY, CAIRO UNIVERSITY. Mediterranean Archaeology \& Archaeometry, 16(2), pp.1-11. 